\title{
Copper Nanoparticles in Click Chemistry
}

\author{
2 Francisco Alonso, ${ }^{* \dagger}$ Yanina Moglie, ${ }^{\ddagger}$ and Gabriel Radivoy \\ $3{ }^{\dagger}$ Instituto de Síntesis Orgánica (ISO) and Departamento de Química Orgánica, Facultad de Ciencias, Universidad de Alicante, Apdo. \\ 4 99, E-03080 Alicante, Spain \\ 5 "Departamento de Química, Instituto de Química del Sur (INQUISUR-CONICET), Universidad Nacional del Sur, Avenida Alem \\ 6 1253, 8000 Bahía Blanca, Argentina
}

7 CONSPECTUS: The challenges of the 21st century demand scientific and technological achievements that must be developed under sustainable and environmentally benign practices. In this vein, click chemistry and green chemistry walk hand in hand on a pathway of rigorous principles that help to safeguard the health of our planet against negligent and uncontrolled production. Copper-catalyzed azide-alkyne cycloaddition (CuAAC), the paradigm of a click reaction, is one of the most reliable and widespread synthetic transformations in organic chemistry, with multidisciplinary applications. Nanocatalysis is a green chemistry tool that can increase the inherent effectiveness of CuAAC because of the enhanced catalytic activity of nanostructured metals and their plausible reutilization capability as heteroge-

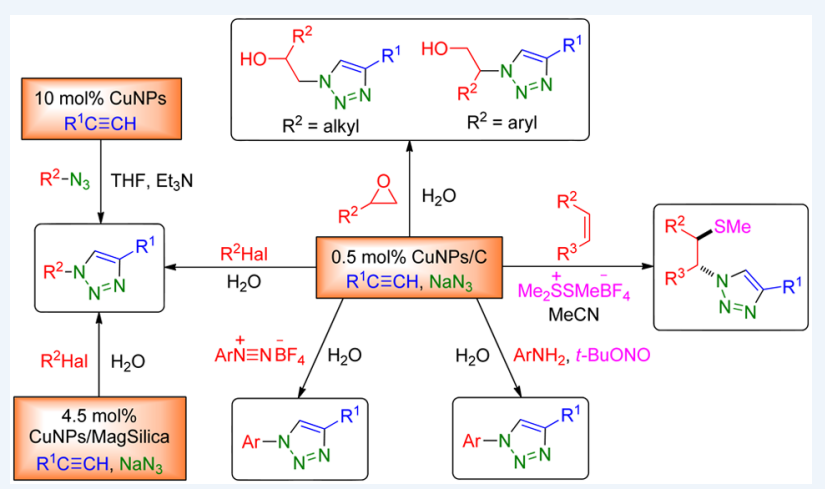
neous catalysts.

This Account describes our contribution to click chemistry using unsupported and supported copper nanoparticles (CuNPs) as catalysts prepared by chemical reduction. $\mathrm{Cu}(0) \mathrm{NPs}(3.0 \pm 1.5 \mathrm{~nm})$ in tetrahydrofuran were found to catalyze the reaction of terminal alkynes and organic azides in the presence of triethylamine at rates comparable to those achieved under microwave heating (10-30 $\mathrm{min}$ in most cases). Unfortunately, the CuNPs underwent dissolution under the reaction conditions and consequently could not be recovered. Compelling experimental evidence on the in situ generation of highly reactive copper(I) chloride and the participation of copper(I) acetylides was provided.

The supported CuNPs were found to be more robust and efficient catalyst than the unsupported counterpart in the following terms: (a) the multicomponent variant of CuAAC could be applied; (b) the metal loading could be substantially decreased; (c) reactions could be conducted in neat water; and $(\mathrm{d})$ the catalyst could be recovered easily and reutilized. In particular, the catalyst composed of oxidized $\mathrm{CuNPs}\left(\mathrm{Cu}_{2} \mathrm{O} / \mathrm{CuO}, 6.0 \pm 2.0 \mathrm{~nm}\right)$ supported on carbon $(\mathrm{CuNPs} / \mathrm{C})$ was shown to be highly versatile and very effective in the multicomponent and regioselective synthesis of 1,4-disubstituted 1,2,3-triazoles in water from organic halides as azido precursors; magnetically recoverable CuNPs $(3.0 \pm 0.8 \mathrm{~nm})$ supported on MagSilica could be alternatively used for the same purpose under similar conditions. Incorporation of an aromatic substituent at the 1-position of the triazole could be accomplished using the same CuNPs/C catalytic system starting from aryldiazonium salts or anilines as azido precursors. $\mathrm{CuNPs} / \mathrm{C}$ in water also catalyzed the regioselective double-click synthesis of $\beta$-hydroxy-1,2,3-triazoles from epoxides. Furthermore, alkenes could be also used as azido precursors through a one-pot CuNPs/C-catalyzed azidosulfenylation-CuAAC sequential protocol, providing $\beta$-methylsulfanyl-1,2,3-triazoles in a stereo- and regioselective manner. In all types of reaction studied, CuNPs/C exhibited better behavior than some commercial copper catalysts with regard to the metal loading, reaction time, yield, and recyclability. Therefore, the results of this study also highlight the utility of nanosized copper in click chemistry compared with bulk copper sources.

\section{INTRODUCTION}

${ }_{41}$ Click chemistry is a conception of organic synthesis that is of 42 paramount importance in modern chemistry. ${ }^{1}$ To paraphrase 43 Sharpless and co-workers, click chemistry "represents certain 44 highly efficient and reliable reactions which are modular, wide 45 in scope, high yielding, stereospecific, proceed under simple 46 and benign conditions and involve straightforward procedures 47 for product isolation". Copper-catalyzed azide-alkyne cyclo48 addition (CuAAC) stands out among this group of select 49 reactions since the capital discovery by the teams of $\mathrm{Meldal}^{2}$ 50 and Sharpless ${ }^{3}$ in the dawn of the 21 st century, namely, the dramatic acceleration of the Huisgen ${ }^{4}$ 1,3-dipolar cycloaddition 51 reaction of organic azides and alkynes under copper(I) catalysis 52 and mild conditions, together with high regioselectivity toward 53 the 1,4-regioisomer of the triazole (Scheme 1). ${ }^{5}$ The first $54 \mathrm{~s} 1$ decade of click chemistry has recently been commemorated; ${ }^{6}{ }_{55}$ throughout this time, an increasing number of disciplines ${ }^{7}$ have 56 taken advantage of the unique benefits offered by $\mathrm{CuAAC}$, the 57 click reaction par antonomasia.

Received: April 27, 2015 
Scheme 1. Huisgen and CuAAC Syntheses of 1,2,3-Triazoles

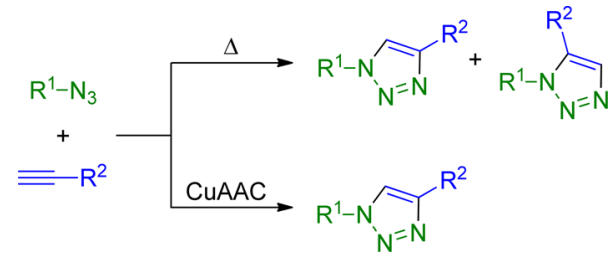

59 Green chemistry $^{8}$ shares with click chemistry some of the 60 aforementioned stringent criteria, by means of which more 61 efficient and environmentally benign processes can be 62 delineated and implemented. In this context, nanocatalysis 63 has arisen as a competitive and sustainable alternative to 64 traditional catalysis because of the high surface-to-volume ratio 65 of the nanoparticles, which hightens their activity and 66 selectivity, preserving the inherent characteristics of a 67 heterogeneous catalyst. ${ }^{9}$ Particularly, inorganic supports with 68 high surface area can be used to immobilize metal nanoparticles 69 and obtain specially active and recyclable catalysts as a result of 70 the higher stability and dispersion of the particles. ${ }^{10}$ 71 Furthermore, the combined use of water as a solvent with 72 metal nanoparticles is a fast-growing area in response to the 73 general upsurge of interest in minimizing the environmental 74 impact of chemistry. ${ }^{11}$ With these principles in mind, new 75 possibilities have arisen for the paradigmatic click reaction.

76 CuAAC is typically accomplished using copper(I) sources, 77 including (a) copper(I) salts, (b) in situ reduction of 78 copper(II) salts, and (c) comproportionation of copper(0) 79 and copper(II). In 2005, stoichiometric copper metal, in the 80 form of turnings or powder, was found to be a source of the 81 catalytic species implicated in the click reaction. ${ }^{12}$ Thereafter, 82 the use of copper nanoparticles (CuNPs) has been increasingly 83 explored as an alternative to bulk copper. ${ }^{13}$

84 As a result of our interest in metal colloids ${ }^{14}$ and initial 85 studies on active copper [produced by reduction of copper(II) 86 chloride dihydrate with lithium metal and a catalytic amount of 87 4,4'-di-tert-butylbiphenyl (DTBB) in tetrahydrofuran 88 (THF) ${ }^{15}$ the formation of CuNPs from either $\mathrm{CuCl}_{2} \cdot 2 \mathrm{H}_{2} \mathrm{O}$ 89 or anhydrous $\mathrm{CuCl}_{2}$ was discovered under the above90 mentioned conditions. Herein we present our contribution to the field of click chemistry by means of both unsupported and 91 supported CuNPs catalysts. Preformed organic azides and 92 terminal alkynes are used as starting materials in the first case; 93 in the second case, a multicomponent approach is tackled from 94 different azido precursors, sodium azide, and terminal alkynes. 95 It must be pointed out that although this Account is focused on 96 heterogeneous catalysis, the fundamental contribution of 97 homogeneous catalysis to the advance of click chemistry must 98 not be disregarded; speeding up the CuAAC reaction at room 99 temperature and decreasing the amounts of copper to levels of 100 a few parts per million are some praiseworthy achievements of 101 homogeneous CuAAC. ${ }^{16}$

102

\section{DISCUSSION}

\subsection{Unsupported CuNPs in Click Chemistry}

Unsupported CuNPs have been scarcely studied in CuAAC 103 compared with the supported counterparts; the inherent 104 tendency toward particle agglomeration makes the presence 105 of stabilizing agents or solid supports mandatory in most cases. 106 Pioneering work by the groups of Rothenberg ${ }^{17 a}$ and 107 Orgueira $^{1 / 6}$ with $\mathrm{Cu}(0)$ nanoclusters was followed by the use 108 of mixed $\mathrm{Cu} / \mathrm{Cu}$ oxide nanoparticles ${ }^{17 \mathrm{c}}$ and poly- 109 (vinylpyrrolidone)-stabilized CuNPs, ${ }^{17 \mathrm{~d}}$ all of which catalyzed 110 the reaction of preformed azides and terminal alkynes. 111

Our group prepared $\mathrm{Cu}(0) \mathrm{NPs}$ by fast chemical reduction of 112 anhydrous copper(II) chloride with lithium metal and a 113 catalytic amount of DTBB as an electron carrier in THF at 114 room temperature under argon in the absence of any added 115 nucleation or antiagglomeration agent (Figure 1); the chloride $116 \mathrm{fl}$ anion (accompanied by its $\mathrm{Li}$ counteranion, derived from the 117 reductant $)^{18 \mathrm{a}}$ and, to a lesser extent, the solvent $(\mathrm{THF})^{18 \mathrm{~b}} 118$ stabilized the nanoparticles by electrostatic forces. Character- 119 ization by transmission electron microscopy (TEM), X-ray 120 photoelectron spectroscopy (XPS), powder X-ray diffraction 121 (XRD), energy-dispersive X-ray analysis (EDX), and selected- 122 area electron diffraction (SAED) brought into view spherical 123 face-centered-cubic copper $(0)$ nanoparticles with a particle size 124 distribution of ca. $3.0 \pm 1.5 \mathrm{~nm}^{19}$

The as-prepared nanoparticles were found to catalyze (10 126 mol \%) the reaction of azides and terminal alkynes using 127 triethylamine as the base in THF at $65{ }^{\circ} \mathrm{C}$ under argon. 128

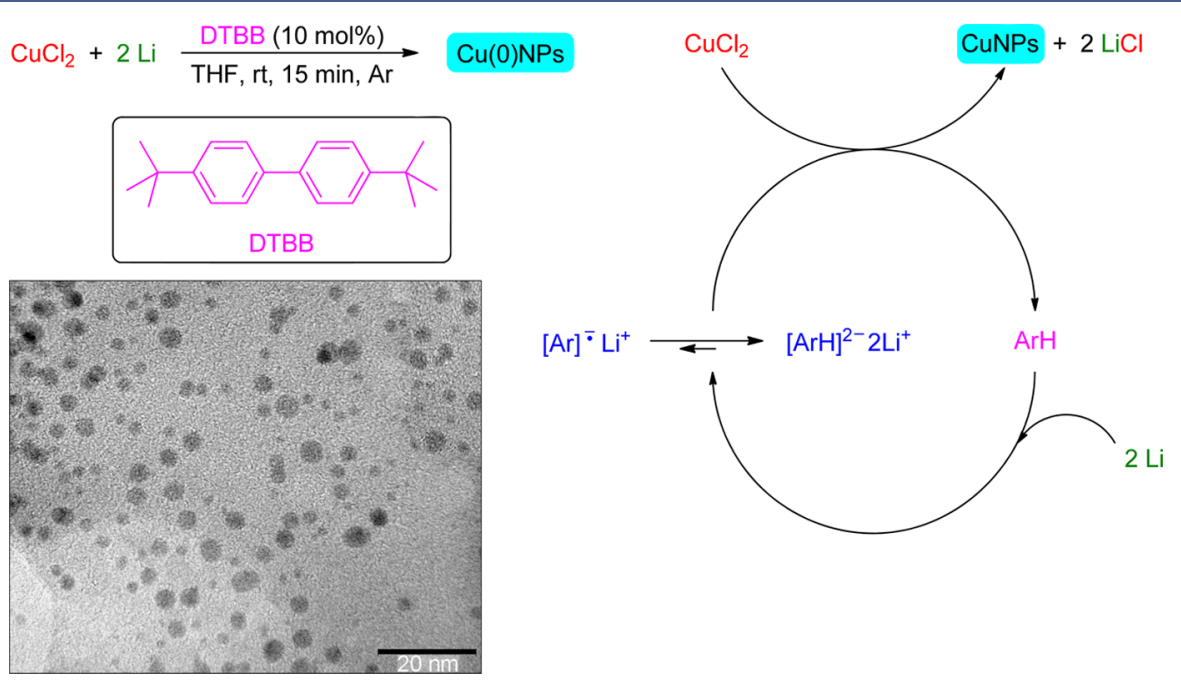

Figure 1. Synthesis and TEM micrograph of the CuNPs. The TEM micrograph is reproduced with permission from ref 19 a. Copyright 2009 Elsevier. 
Table 1. AAC Catalyzed by Unsupported CuNPs

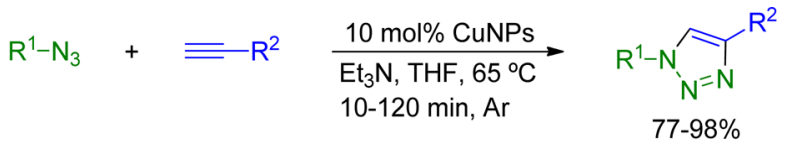

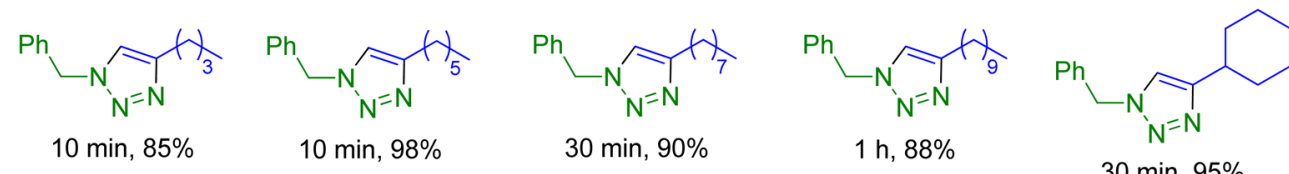<smiles>c1ccc(CCc2cn(Cc3ccccc3)nn2)cc1</smiles>

$10 \mathrm{~min}, 90 \%$<smiles>c1ccc(Cn2cc(-c3ccccc3)nn2)cc1</smiles>

$10 \min , 98 \%$<smiles>C1=C(c2cn(Cc3ccccc3)nn2)CCCC1</smiles>

$30 \mathrm{~min}, 97 \%$<smiles>OCc1cn(Cc2ccccc2)nn1</smiles>

$30 \min , 97 \%$<smiles>OC1(c2cn(Cc3ccccc3)nn2)CCCCC1</smiles>

$1 \mathrm{~h}, 92 \%$<smiles>CCCCc1cn(-c2ccccc2)nn1</smiles><smiles>c1ccc(-n2cc(C3CCCCC3)nn2)cc1</smiles>
$30 \mathrm{~min}, 94 \%$<smiles>OC1(c2cn(-c3ccccc3)nn2)CCCCC1</smiles>
$1 \mathrm{~h}, 85 \%$

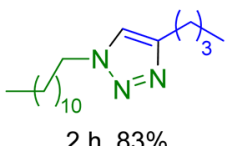

2 h, $83 \%$<smiles>Cc1cn(C2CCCCC2)nn1</smiles>

2 h, $95 \%$<smiles>c1ccc(-c2cn(C3CCCCC3)nn2)cc1</smiles>

$30 \mathrm{~min}, 87 \%$<smiles>C(=Cc1ccccc1)Cn1cc(C=Cc2ccccc2)[n+](-c2ccccc2)n1</smiles>

$10 \min , 97 \%$

2 h, $90 \%$

2 h, $80 \%$<smiles>C(=C/c1ccccc1)\Cn1cc(/C=C/Cn2cc(/C=C/c3ccccc3)nn2)nn1</smiles>

$1 \mathrm{~h}, 96 \%$<smiles>CC(=O)c1ccc(-n2cc(C)nn2)cc1</smiles>
$2 \mathrm{~h}, 82 \%$<smiles>CCOC(=O)Cn1cc(C2=CCCCC2)nn1</smiles>
$1 \mathrm{~h}, 78 \%$ $1 \mathrm{~h}, 95 \%$<smiles>C(=Cc1ccccc1)Cn1cc(C=Cc2ccccc2)nn1</smiles>

$1 \mathrm{~h}, 89 \%$<smiles>C(=C/c1ccccc1)\CCc1cn(CCc2ccccc2)nn1</smiles>

2 h, $92 \%$<smiles>CC(=O)c1ccc(-n2cc(CCc3ccccc3)nn2)cc1</smiles>

$2 \mathrm{~h}, 85 \%$<smiles>CC(=O)c1ccc(-n2cc(C3(O)CCCCC3)nn2)cc1</smiles>

$2 \mathrm{~h}, 85 \%$<smiles>CCOC(=O)Cn1cc(-c2ccccc2)nn1</smiles>

$30 \mathrm{~min}, 88 \%$<smiles></smiles>

2 h, $77 \%$<smiles>C[C@]1(c2cn(Cc3ccccc3)nn2)CC[C@H]2CCc3cc(O)ccc3[C@@H]2CC1</smiles>

$30 \mathrm{~min}, 98 \%$
129 Notably, all of the reactions were run for $10-120 \mathrm{~min}$ in the 130 absence of any stabilizing additive or ligand, with these times 131 being equivalent to those formerly reported under microwave 132 heating. ${ }^{20}$ The corresponding 1,2,3-triazoles were obtained in 133 excellent isolated yields after simple workup manipulation such 134 as filtration and crystallization or solvent evaporation (Table 1). 135 The CuNPs in THF exhibited superior catalytic activity in 136 comparison with some commercial copper catalysts, but 137 unfortunately, their dissolution under the reaction conditions 138 precluded their reuse.

139 Much debate has arisen concerning the mechanism of 140 CuAAC. ${ }^{21}$ On the basis of different experiments, ${ }^{19 b}$ a reaction 141 mechanism was proposed wherein copper(I) acetylides 142 appeared as the true intermediate species (Scheme 2). In this 143 mechanism, the in situ generation of $\mathrm{CuCl}$ was postulated, after 144 acetylene deprotonation, with the concomitant formation of 145 triethylammonium chloride (in the presence of $\mathrm{LiCl}$ from the 146 preparation of the CuNPs), and the action of the latter on the
CuNPs. The reaction of the nascent copper(I) chloride with 147 the acetylide species would furnish the corresponding copper- 148 (I) acetylide. From this stage, the catalytic cycle would be akin 149 to that published by others, ${ }^{12 a, 22}$ with special mention of the 150 recent one disclosed by Fokin and co-workers involving a 151 dinuclear copper intermediate. ${ }^{22}$ The eventual protonolysis of 152 the resulting copper(I) triazolide complex ${ }^{22 a}$ by triethylammo- 153 nium chloride would lead to the triazole product and 154 regeneration of $\mathrm{CuCl}$.

\subsection{Supported CuNPs in Click Chemistry}

2.2.1. Introduction. Many procedures have been put into 156 practice in order to expand the possibilities to apply CuAAC ${ }_{157}$ and increase its efficiency. Among them, those involving three 158 key features in modern synthetic organic chemistry are 159 considered of special interest: (a) multicomponent reactions, 160 in which isolation and manipulation of the organic azides is 161 unnecessary since they are produced in situ, thereby 162 
Scheme 2. Selected Experiments for AAC Catalyzed by CuNPs and a Catalytic Cycle with Intermediates Proposed by Others

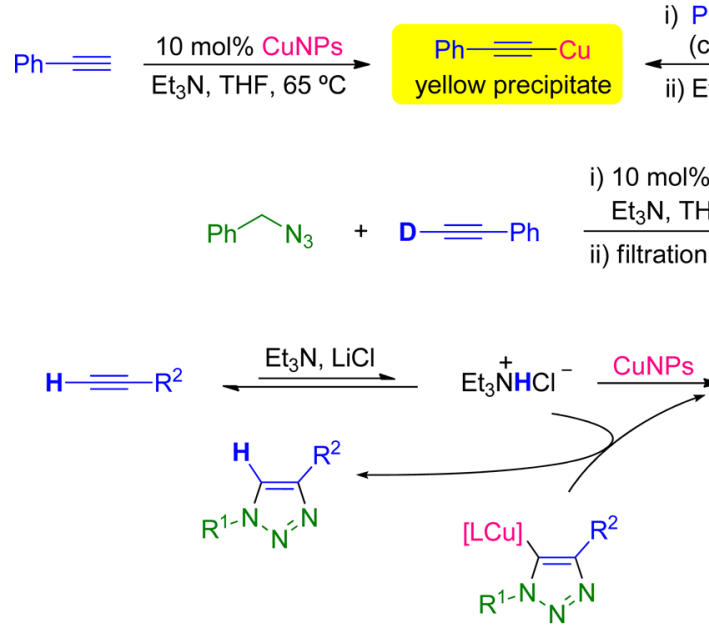

[Straub et al. $\left.{ }^{22 a}\right]$

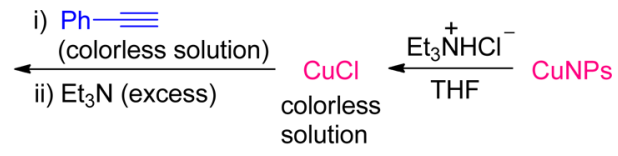

$99.5 \%$ D
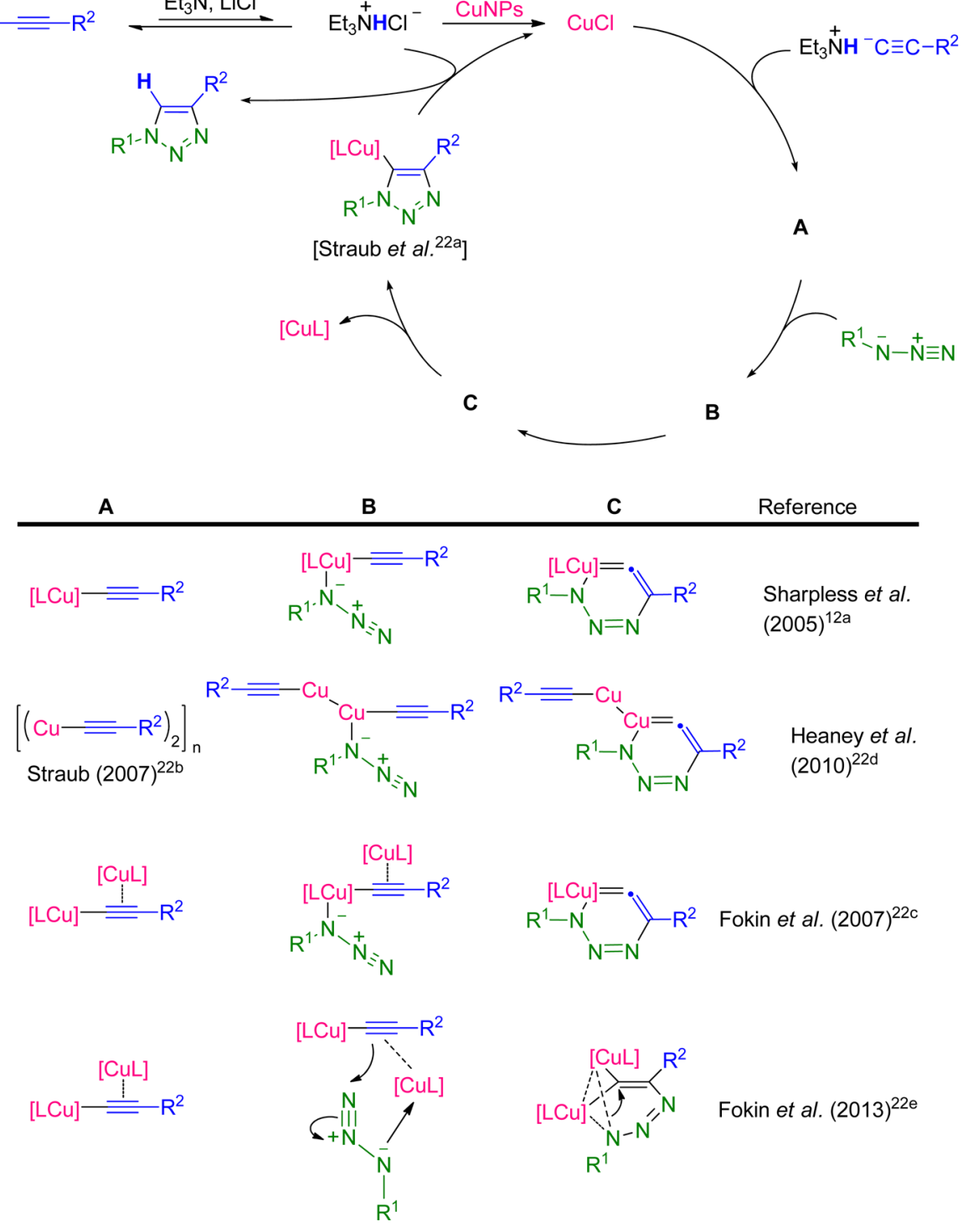

A

163 diminishing risks, shortening reaction times, and reducing 164 waste; (b) heterogeneous catalysis, above all nanocatalysis, 165 which is favorable with respect to the homogeneous analogue 166 because the catalyst is more stable and can be often recovered 167 and reused; and (c) the use of aqueous media, which has a 168 beneficial effect on the economy and safety of production as 169 well as in the environment.

170 In this sense, various articles on heterogeneous $\mathrm{CuAAC}$ have 171 appeared in the literature. ${ }^{23}$ Catalysts based on copper(I) 172 immobilized on different supports, such as charcoal, ${ }^{23 a}$ 173 zeolites, ${ }^{23 b}$ ionic polymers, ${ }^{23 c}$ aluminum oxyhydroxide fibers, ${ }^{23 \mathrm{~d}}$ 174 and Amberlyst A-21, ${ }^{23 e}$ are advantageous because of their easy

recovery and reutilization potential. All of these examples, 175 however, involved preformed organic azides.

The one-pot synthesis of 1,4-disubstituted 1,2,3-triazoles 177 from in situ-generated azides was originally developed by Fokin 178 and co-workers. ${ }^{24}$ Later on, silica ${ }^{25 a}$ and zeolites ${ }^{25 b}$ were used 179 as supports for the copper-catalyzed heterogeneous version of 180 the one-pot synthesis. In regard to the latter heterogeneous 181 multicomponent approach but using nanocatalysis, CuNPs 182 supported on $\mathrm{Al}_{2} \mathrm{O}_{3}$ catalyzed the synthesis of 1,2,3-triazoles 183 from activated organic halides at room temperature in water; ${ }^{26 a} 184$ the catalyst was reused over three cycles. A highly reusable 185 catalyst consisting of CuI/Cu NPs $(80-300 \mathrm{~nm})$ on pretreated 186 activated carbon was successfully applied to the three- 187 


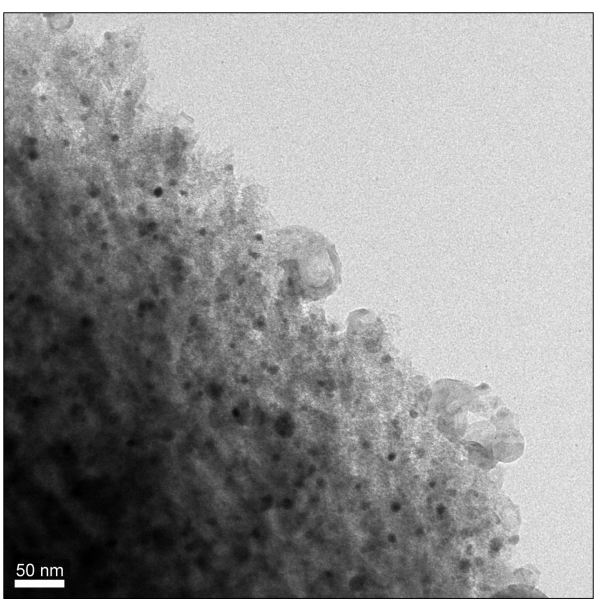

Figure 2. TEM micrograph of CuNPs/C. Reproduced with permission from ref 27a. Copyright 2010 John Wiley \& Sons.

188 component reaction of activated organic halides in water at 100 $189{ }^{\circ} \mathrm{C} .{ }^{26}$

190 2.2.2. Multicomponent Synthesis of 1,2,3-Triazoles 191 from Organic Halides as Azido Precursors Catalyzed by 192 CuNPs/C. In order to upgrade the previous unsupported 193 catalytic system and overcome the nonrecyclability short- coming, a variety of supported copper catalysts were obtained 194 by addition of an inorganic support to a suspension of the 195 freshly prepared CuNPs followed by filtration and drying. The 196 catalysts were not submitted to any thermal or activation 197 treatment but were used in the three-component CuAAC 198 reaction as prepared, with CuNPs supported on carbon 199 (CuNPs/C) being the most efficient. ${ }^{27}$ Analysis by TEM, 200 EDX, XPS, and SAED unveiled the presence of spherical 201 $\mathrm{Cu}_{2} \mathrm{O} / \mathrm{CuO}$ NPs dispersed on the active carbon support with 202 an average size of ca. $6.0 \pm 2.0 \mathrm{~nm}$ (Figure 2). 203 f 2

The catalyst, at low loading $(0.5 \mathrm{~mol} \%)$ and in the absence 204 of triethylamine, was applied to the synthesis of 1,4- 205 disubstituted 1,2,3-triazoles through multicomponent CuAAC 206 in water at $70{ }^{\circ} \mathrm{C}$ (Table 2). A wide range of triazoles, including $207 \mathrm{t} 2$ one bicyclic triazole and bistriazoles, were synthesized from 208 activated or nonactivated organic halides (chlorides, bromides, 209 and iodides) and different terminal alkynes. Deactivated alkyl 210 halides worked better in a 1:1 $\mathrm{H}_{2} \mathrm{O} / \mathrm{EtOH}$ solvent system, 211 whereas the combination of deactivated alkyl halides and 212 aliphatic alkynes was found to be more reluctant to react. To 213 the best of our knowledge, this was the first report describing 214 the use of oxidized CuNPs in the multicomponent variant of 215 the click reaction.

216

Furthermore, this method was found to be equally effectual 217 and straightforward for the preparation of some potentially 218

Table 2. Three-Component CuAAC from Organic Halides as Azido Precursors

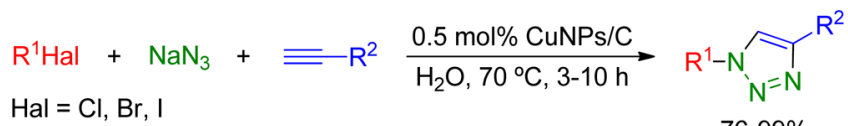

$$
\begin{aligned}
& \text { 76-99\% }
\end{aligned}
$$

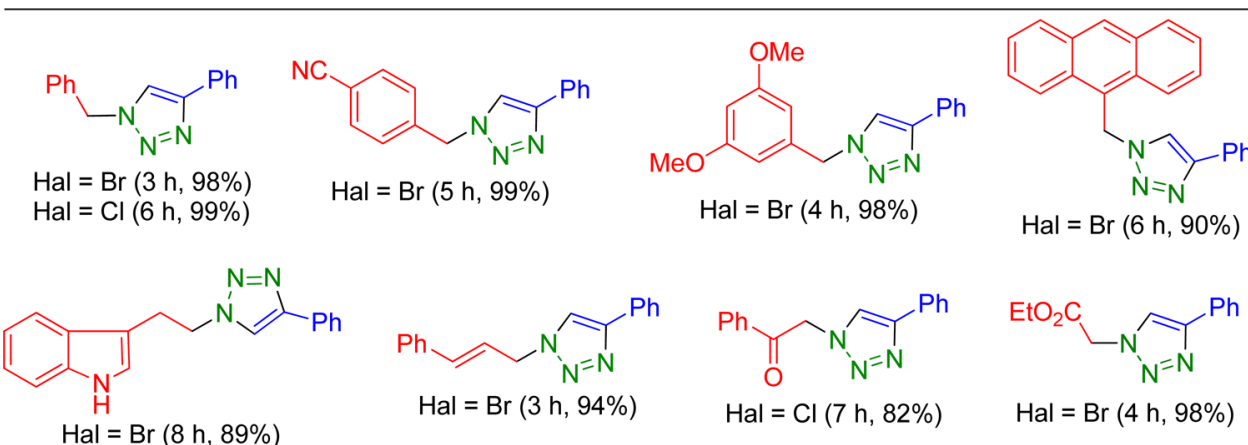<smiles>CCCn1cc(-c2ccccc2)nn1</smiles>

$\mathrm{Hal}=\mathrm{I}(5 \mathrm{~h}, 98 \%)^{\mathrm{a}}$ $\mathrm{Hal}=\mathrm{Cl}(8 \mathrm{~h}, 94 \%)^{b}$

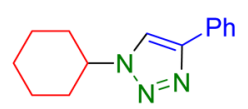

$\mathrm{Hal}=\mathrm{Br}(8 \mathrm{~h}, 93 \%)^{a}$

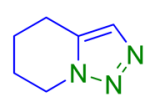

$(8 \mathrm{~h}, 89 \%)^{c}$<smiles>Brc1cn(C2CCCCC2)nn1</smiles>

$\mathrm{Hal}=\mathrm{I}(8 \mathrm{~h}, 92 \%)^{a, b}$

$$
\mathrm{H}_{7} \mathrm{~N}_{\mathrm{N}=\mathrm{N}} \mathrm{HH}_{4}
$$

$\mathrm{Hal}=\mathrm{I}(8 \mathrm{~h}, 92 \%)^{a, b}$

$$
\overbrace{N_{N}=\mathrm{N}} \mathrm{O}^{-P h}
$$

$\mathrm{Hal}=\mathrm{Br}(7 \mathrm{~h}, 76 \%)$<smiles>O=C1c2ccccc2C(=O)N1Cc1cn(Cc2ccccc2)nn1</smiles>

$\mathrm{Hal}=\mathrm{Br}(8 \mathrm{~h}, 84 \%)$<smiles>COc1ccc(-c2cn(Cc3ccccc3)nn2)cc1</smiles>

$\mathrm{Hal}=\mathrm{Br}(6 \mathrm{~h}, 90 \%)$<smiles>c1ccc(Cn2cc(-c3ccccn3)nn2)cc1</smiles>

$\mathrm{Hal}=\mathrm{Br}(6 \mathrm{~h}, 92 \%)$<smiles>CSc1cn(Cc2ccccc2)nn1</smiles>

$\mathrm{Hal}=\mathrm{Br}(8 \mathrm{~h}, 82 \%)$<smiles>c1ccc(Cn2cc(-c3cccc(-c4cn(Cc5ccccc5)nn4)c3)nn2)cc1</smiles>

$\mathrm{Hal}=\mathrm{Br}(6 \mathrm{~h}, 92 \%)$

${ }^{a}$ Reaction in 1:1 H $\mathrm{H}_{2} \mathrm{O} / \mathrm{EtOH} .{ }^{b}$ Reaction at $100{ }^{\circ} \mathrm{C} .{ }^{c}$ From 6-chlorohex-1-yne. 
Table 3. Synthesis of Potentially Biologically Active Triazoles

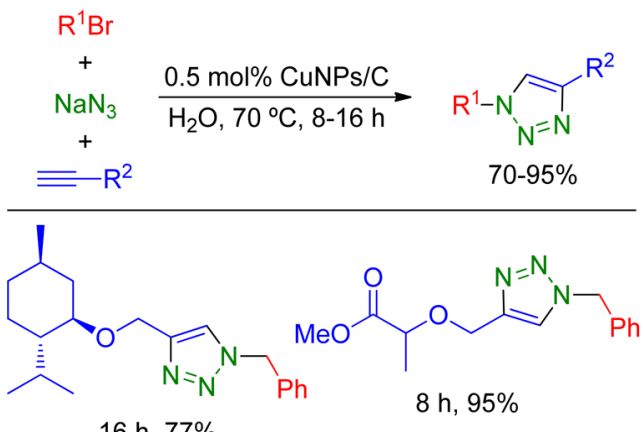

$16 \mathrm{~h}, 77 \%$<smiles>CC(C)CCC[C@H](C)[C@H]1CC[C@H]2[C@H]3CC=C4C[C@@H](OCc5cn(Cc6ccccc6)nn5)CC[C@]4(C)[C@H]3CC[C@]21C</smiles>

$16 \mathrm{~h}, 75 \%$<smiles>CC12CCC3c4ccc(OCc5cn(Cc6ccccc6)nn5)cc4CCC3[C@H]1CCC2=O</smiles>

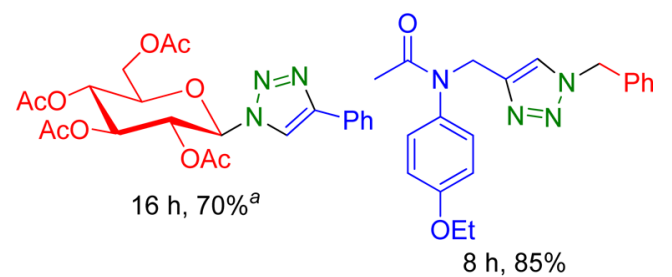

$8 \mathrm{~h}, 85 \%$

${ }^{a}$ Reaction at $100{ }^{\circ} \mathrm{C}$.

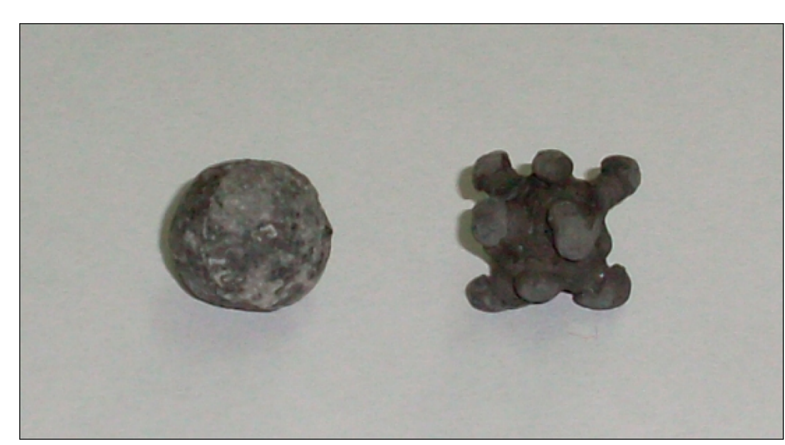

Figure 3. Triazole products covered with CuNPs/C [ca. $8 \mathrm{~mm}$ (left) and $10 \mathrm{~mm}$ (right)]. Reproduced with permission from ref $27 \mathrm{~b}$. Copyright 2011 The Royal Society of Chemistry).

219 biologically active compounds. ${ }^{28}$ A series of new triazoles 220 derived from the natural products (-)-menthol, lactic acid, D221 glucose, estrone, and cholesterol and from the synthetic 222 compound phenacetin were obtained in good to excellent 223 isolated yields (Table 3 ).

224 2.2.3. Nature of the CuNPs/C Catalyst. ${ }^{27 b}$ It is worth 225 mentioning that the progress of the reactions catalyzed by $226 \mathrm{CuNPs} / \mathrm{C}$ in water could be followed visually: at the end of the
Scheme 3. Experiments on the Nature of the Catalysis
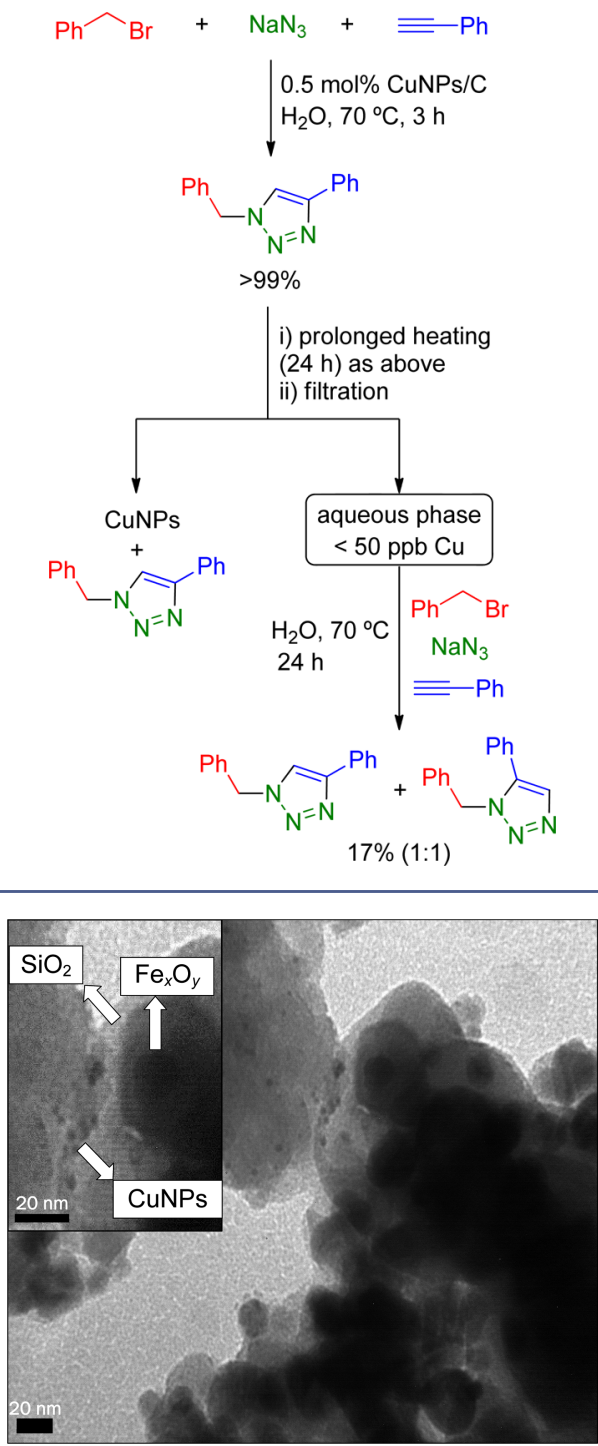

Figure 4. TEM micrograph of CuNPs/MagSilica. Reproduced with permission from ref 30. Copyright 2013 Elsevier.

reaction, one solid aggregate comprising a triazole nucleus and 227 a catalyst cover could be observed at the top of a colorless and 228 transparent solution. The black pieces (white inside) looked 229 almost spherical or had a contour reminiscent of a virus or a 230 naval mine (Figure 3). These shapes can be ascribed to the $231 \mathrm{f} 3$ intermolecular forces acting between two hydrophobic solids in 232 an aqueous liquid.

Even though the amount of catalyst deployed in these 234 reactions was small, it could be retrieved by simple filtration 235 and reutilized, leading to outstanding yields of the triazole 236 product in five consecutive runs (98-90\%) with undetectable 237 copper leaching. In order to unveil the nature of the catalysis, 238 the following protocol was carried out: the mixture resulting 239 from a standard reaction, which contained the 1,2,3-triazole, 240 was further warmed for $24 \mathrm{~h}$ with the aim of leaching some 241 metal into the solution (Scheme 3). After removal of the $242 \mathrm{~s} 3$ catalyst and the product by filtration, the water filtrate was 243 subjected to extraction with ethyl acetate, and new starting 244 materials were added to the obtained aqueous phase. When the 245 resulting biphasic liquid was enabled to react by heating at 70246 
Table 4. Three-Component CuAAC from Organic Halides as Azido Precursors

$$
\text { (1) }
$$

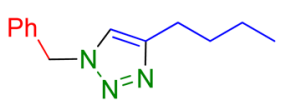

${ }^{a}$ Reaction at $100{ }^{\circ} \mathrm{C}$.

$247{ }^{\circ} \mathrm{C}$ for $24 \mathrm{~h}$, the 1,2,3-triazole was obtained in $17 \%$ conversion 248 as a ca. 1:1 ratio of the 1,4- and 1,5-disubstituted regioisomers. 249 This result proved that the reaction took place under thermal 250 conditions in a noncatalyzed mode, which could be asserted by 251 determining the copper content of the resulting aqueous phase $252(<50 \mathrm{ppb} \mathrm{Cu})$. Although all of these experiments denote a 253 process that is heterogeneous in nature, the possibility that the 254 catalyst operates as a reservoir for metal species that leach into 255 solution and readsorb cannot be ruled out. ${ }^{18 a}$ Nevertheless, 256 Scaiano and co-workers recently combined single-molecule 257 spectroscopy with standard bench-scale techniques to examine 258 the CuNP-catalyzed AAC and proved that the catalysis occurs 259 at the surface of the CuNPs. ${ }^{29}$

260 2.2.4. Multicomponent Synthesis of 1,2,3-Triazoles 261 from Organic Halides as Azido Precursors Catalyzed by 262 CuNPs/MagSilica. Commercially available silica-coated ma263 ghemite nanoparticles (MagSilica, 5-30 nm) were also 264 deployed as a support for CuNPs, the suspension of which 265 was readily generated from anhydrous copper(II) chloride, 266 lithium sand, and a catalytic amount of DTBB (10 mol \%) in $267 \mathrm{THF}$ at room temperature. ${ }^{30}$ TEM revealed the presence of
Table 5. Three-Component Synthesis of 1,2,3-Triazoles from Aryldiazonium Salts as Azido Precursors
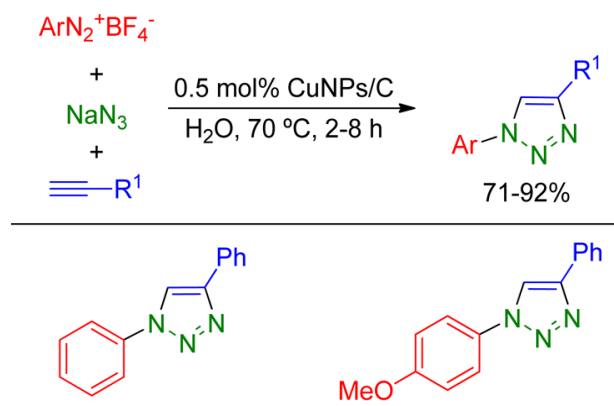

2 h, $85 \%$

$4 \mathrm{~h}, 75 \%$<smiles>CC(=O)c1ccc(-n2cc(-c3ccccc3)nn2)cc1</smiles><smiles>N#Cc1ccc(-n2cc(-c3ccccc3)nn2)cc1</smiles><smiles>O=[N+]([O-])c1ccc(-n2cc(-c3ccccc3)nn2)cc1</smiles><smiles>CSc1cn(-c2ccc([Sb])cc2)nn1</smiles><smiles>COc1ccc(-c2cn(-c3ccccc3)nn2)cc1</smiles><smiles>COc1ccc(-n2cc(-c3ccccn3)nn2)cc1</smiles><smiles>O=[N+]([O-])c1ccc(-n2cc(-c3ccc(C(F)(F)F)cc3)nn2)cc1</smiles>

$\mathrm{nm}$ that were well-dispersed on the magnetic support (Figure $269 \mathrm{f} 4$ 4).

The CuNPs/MagSilica catalyst manifested good performance 271 in the three-component $\mathrm{CuAAC}$ reaction from organic halides 272 using $4.3 \mathrm{~mol} \% \mathrm{Cu}$ in water at $70{ }^{\circ} \mathrm{C}$. This procedure was 273 successfully applied to electronically different arylacetylenes as 274 well as to aliphatic alkynes, though the latter required longer 275 reaction times. Heating at $100{ }^{\circ} \mathrm{C}$ was essential for the less 276 reactive $n$-nonyl iodide, by which the yield could be increased 277 and the reaction time reduced (Table 4). Notably, the mass of $278 \mathrm{t} 4$ leached copper in these experiments was below the detection 279 level of atomic absorption spectroscopy.

2.2.5. Multicomponent Synthesis of 1,2,3-Triazoles from Aryldiazonium Salts and Anilines as Azido 282 Precursors. The synthesis of 1,2,3-triazoles through click 283 chemistry generally involves preformed azides or the more 284 appropriate azides generated in situ from organic halides. In 285 some cases, however, this synthesis is hampered by the 286 substrate availability and functionality, and a functional group 287 transformation preceding the click reaction is imperative. In this 288 
Table 6. Three-Component Synthesis of 1,2,3-Triazoles from Anilines as Azido Precursors

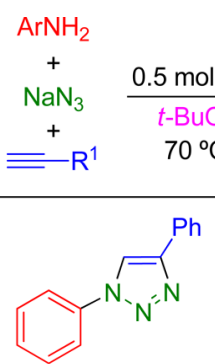

$3 \mathrm{~h}, 90 \%$<smiles>Clc1ccccc1-n1cc(-c2ccccc2)nn1</smiles>

7 h, $64 \%$<smiles>Clc1ccc(-n2cc(-c3ccccc3)nn2)cc1</smiles>
4 h, $78 \%$

$$
3 \mathrm{~h}, 95 \%
$$<smiles>Clc1cccc(-n2cc(-c3ccccc3)nn2)c1</smiles>

$7 \mathrm{~h}, 80 \%$

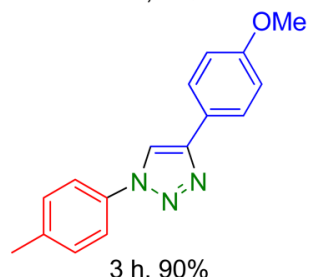<smiles>FC(F)(F)c1ccc(-n2cc(-c3ccccn3)nn2)cc1</smiles>

$3 \mathrm{~h}, 66 \%$

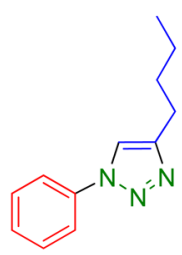

$3 \mathrm{~h}, 93 \%$

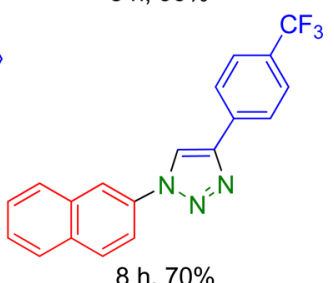

$8 \mathrm{~h}, 70 \%$

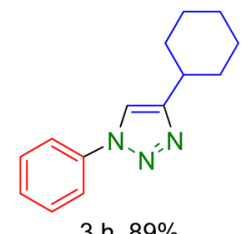

$3 \mathrm{~h}, 89 \%$
289 regard, the versatility of the CuNPs/C catalyst was broadened 290 by investigating some alternative azide precursors other than 291 organic halides that might be suitable to react under the 292 conventional reaction conditions. Diazonium salts were 293 discovered to be alternative substrates to the relatively inert 294 aryl halides and were employed in the three-component 295 synthesis of 1,2,3-triazoles under the same green conditions 296 as practiced for organic halides $(0.5 \mathrm{~mol} \% \mathrm{CuNPs} / \mathrm{C}$, water, 70 $297{ }^{\circ} \mathrm{C}$ ). In this way, aromatic substituents bearing electronically 298 different groups could be incorporated at the 1-position of the 299 triazole in good yields and relatively short reaction times (Table $3005)$. $^{27 b}$

301 The direct use of anilines as azido precursors was first 302 described by Moses and co-workers in 2007. The reaction of 303 anilines with $t$-BuONO and trimethylsilyl azide in $\mathrm{CH}_{3} \mathrm{CN}$ led 304 to aryl azides, which were additionally submitted to the click 305 reaction in one pot. ${ }^{31 a}$ The rate of formation of the triazoles 306 was substantially enhanced by microwave radiation. ${ }^{31 \mathrm{~b}}$ 307 However, because the entire process was sequential, monitoring 308 of the azide formation before the cycloaddition step was 309 indispensable. It was found that anilines could be directly converted into 1,2,3-triazoles with $t$-BuONO and $\mathrm{NaN}_{3}$ under 310 the catalysis of CuNPs/C in aqueous media (Table 6). ${ }^{27 b}$ This 311 t6 multicomponent reaction was more convenient since $\mathrm{NaN}_{3}$ is 312 cheaper than trimethylsilyl azide, the reaction is performed in 313 water, and monitoring of intermediates is avoided. The 314 methodology is applicable to electronically different anilines 315 and arylacetylenes as well as to aliphatic alkynes.

2.2.6. Multicomponent Synthesis of 1,2,3-Triazoles 317 from Epoxides as Azido Precursors. Strained cycles such as 318 epoxides, aziridines, cyclic sulfates, cyclic sulfamidates, 319 aziridinium ions, and episulfonium ions can experience 320 nucleophilic ring opening in a reliable, stereospecific, often 321 highly regioselective, and nearly quantitative manner. These 322 attributes justify the inclusion of this nucleophilic attack into 323 the elite catalogue of click reactions. ${ }^{1}$ Azidolysis of epoxides ${ }^{32} 324$ and $\mathrm{CuAAC}$ share some intrinsic characteristics that utterly 325 adapt the set of strict bases demanded for click chemistry. ${ }^{1}$ For 326 this reason, the synthesis of 1,2,3-triazoles through in situ 327 generation of azido alcohols and further cycloaddition with 328 alkynes has gained increasing attention. ${ }^{33}$ Although the 329 reactions were carried out in one pot, some of the processes 330 were sequential; hence, monitoring of the azido alcohol 331 formation was necessary prior to the alkyne addition. 332

It was demonstrated that CuNPs can catalyze the multi- 333 component synthesis of 1,2,3-triazoles from epoxides as azido 334 precursors. $^{34}$ An array of $\beta$-hydroxytriazoles was synthesized 335 from epoxides, sodium azide, and terminal alkynes in water 336 under the same conditions as above (i.e., $0.5 \mathrm{~mol} \% \mathrm{CuNPs} / \mathrm{C}, 337$ $70{ }^{\circ} \mathrm{C}$ ) (Table 7). This double-click methodology is $338 \mathrm{t} 7$ regiospecific with respect to both the azidolysis of the epoxide 339 and the 1,3-dipolar cycloaddition as follows: “(a) monoalkyl- 340 substituted oxiranes gave rise to secondary $\beta$-hydroxytriazoles; 341 (b) an $S_{\mathrm{N}} 2^{\prime}$ mechanism governed the regiochemistry for vinyl 342 epoxides; (c) monoaryl-substituted oxiranes lead to primary $\beta$ - 343 hydroxytriazoles with inversion of the configuration; and (d) 344 1,4-disubstituted triazoles were solely formed". The regio- and 345 stereochemistry of the products was unequivocally established 346 on the basis of X-ray crystallographic analyses, and it was 347 proved that the regiochemistry of the products had been 348 wrongly assigned in three of the six publications dealing with 349 this topic.

A simple ${ }^{1} \mathrm{H}$ NMR experiment in $\mathrm{CD}_{3} \mathrm{CN}$ was devised to 351 ascertain the regiochemistry of this sort of reaction quickly and 352 unequivocally. ${ }^{34}$ Moreover, the catalyst could be reused with 353 insignificant leaching ( $80 \mathrm{ppb})$ over four runs, affording the 354 product in excellent to good yields (93-70\%). The supported 355 nanoparticulate catalyst was found to perform better than some 356 commercial catalysts with regard to the metal loading, reaction 357 time, and yield. Deuterium labeling essays disclosed the 358 function of the CuNPs, i.e., to augment the acidity of the 359 terminal alkyne (in water and in the absence of base) for 360 acetylide formation. These experiments also indicated the very 361 probable participation of other intermediates, such as copper(I) 362 triazolides.

363

2.2.7. Multicomponent Synthesis of 1,2,3-Triazoles 364 from Alkenes as Azido Precursors. Olefins can be 365 considered the most accessible raw materials that can yield a 366 carbon skeleton. The azasulfenylation of olefins developed by 367 Trost and Shibata in $1982^{35}$ was used as a source of inspiration 368 to potentially transform alkenes into triazoles. In their report, 369 treatment of an alkene with dimethyl(methylthio)sulfonium 370 tetrafluoroborate (DMTSF) was followed by the addition of a 371 nitrogen nucleophile and stirring at ambient temperature for 372 
Table 7. Three-Component Synthesis of $\beta$-Hydroxy-1,2,3-triazoles from Epoxides as Azido Precursors

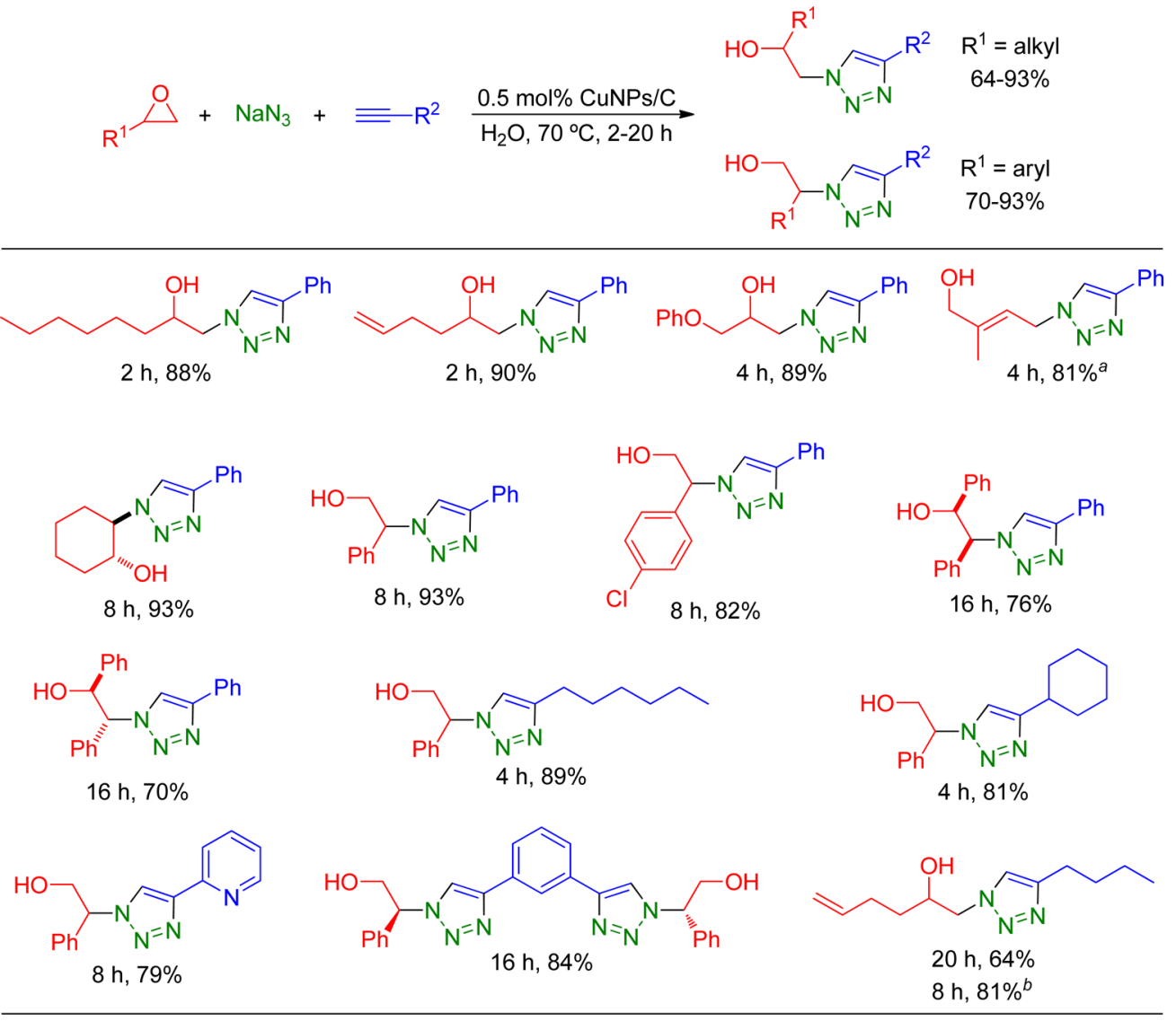

${ }^{a}$ From 2-methyl-2-vinyloxirane. ${ }^{b}$ Reaction at $100{ }^{\circ} \mathrm{C}$.

373 1-4 days. A more convenient variation of this method was 374 discovered by directly mixing the alkene with CuNPs/C, 375 DMTSF, and $\mathrm{NaN}_{3}$ in $\mathrm{MeCN}$, whereby the corresponding 376 methylsulfanyl azide was produced in only $1 \mathrm{~h}$ at room 377 temperature.

378 1,2,3-Triazoles were synthesized in one pot from inactivated 379 alkenes by means of a sequence comprising two click steps 380 catalyzed by CuNPs/C: the alkene azidosulfenylation and the 381 reaction of the in situ-generated organic azide with the terminal 382 alkyne. $^{36}$ The resulting $\beta$-methylsulfanyl-1,2,3-triazoles were 383 obtained regio- and diastereoselectively in $75-91 \%$ yield 384 (Table 8). The regioselectivity observed followed the same 385 trend as in the domino azidolysis-CuAAC of epoxides, 386 although the azidolysis of oct-1-ene oxide ${ }^{34}$ was more 387 regioselective than the azidosulfenylation of oct-1-ene. The 388 fact that CuNPs/C could have a catalytic role in the first 389 synthetic step was undoubtedly evidenced by effecting two tests 390 (Scheme 4): (a) the reaction of cyclohexene with DMTSF and $391 \mathrm{NaN}_{3}$ in $\mathrm{MeCN}$ at rt $(1-24 \mathrm{~h})$ gave multiple products and only 392 a 5-24\% yield of the expected azide; (b) under the same 393 conditions but in the presence of $0.5 \mathrm{~mol} \% \mathrm{CuNPs} / \mathrm{C}$, that 394 azide was formed quantitatively in only $1 \mathrm{~h}$. Even though 395 catalyst reutilization was inefficient in this case, very probably 396 because of poisoning by sulfur, the catalytic activity of the 397 nanocatalyst was greater than that of some commercially 398 accessible copper sources in bulk form, which failed in the 399 azidosulfenylation step. Additionally, 1-vinyl-4-substituted or 4400 monosubstituted 1,2,3-triazoles were efficiently made by the subsequent application of simple and quantitative oxidation- $401 \mathrm{s5}$ elimination procedures (Scheme 5).

402 s5

2.2.8. Unsupported versus Supported CuNPs. The 403 catalytic systems and methodologies described herein for 404 CuAAC using supported CuNPs are distinctly more advanta- 405 geous than those based on unsupported CuNPs. In fact, the 406 former meet most of the ideals of green chemistry ${ }^{8}$ and 407 foundations of click chemistry: ${ }^{1}$ (a) waste is reduced to a 408 sodium salt aqueous solution, as the azides are generated in 409 situ; (b) all of the experiments were safe, and no explosion 410 occurred; (c) three or four materials are integrated into the 411 final triazole, hence providing high atom economy; (d) the 412 manipulation of potentially explosive organic azides is circum- 413 vented; (e) neat water or ethanol/water are used as solvents 414 (except in the alkene azidosulfenylation-CuAAC sequence); 415 (e) the preparation of the catalyst is simple and conducted at 416 room temperature; (f) derivatization is minimized; (g) the 417 metal load is low, and the catalyst is recyclable; $(\mathrm{h})$ the progress 418 of the reaction can be checked visually; (j) the methodology is 419 versatile, as a single catalyst can be applied to a variety of 420 starting materials in the same medium; (k) reactions are of 421 wide scope and high-yielding; (l) all of the necessary chemicals 422 are commercially or readily available; (m) simple reaction 423 conditions are employed that are compatible with the presence 424 of oxygen and water (except in the alkene azidosulfenylation- 425 CuAAC sequence); ( $n$ ) both the nucleophilic opening of 426 strained rings and the formation of 1,4-disubstituted 1,2,3-427 triazoles are highly regioselective; and (o) the products 428 generally are easily isolated or do not need purification. $\quad 429$ 
Table 8. Three-Component Synthesis of $\beta$-Methylsulfanyl-1,2,3-triazoles from Alkenes as Azido Precursors

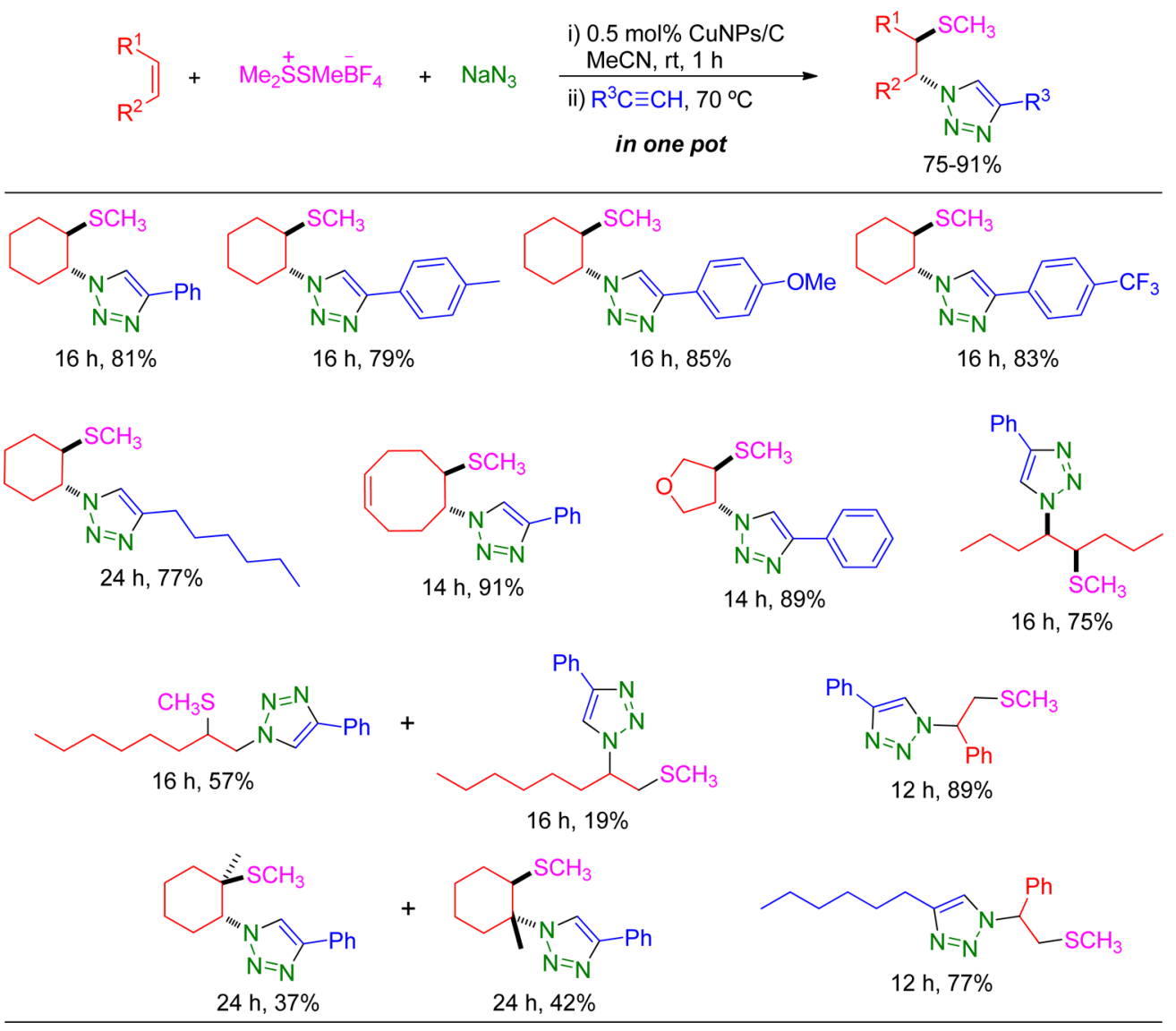

Scheme 4. Catalytic Role of CuNPs/C in the Azidosulfenylation of Cyclohexene

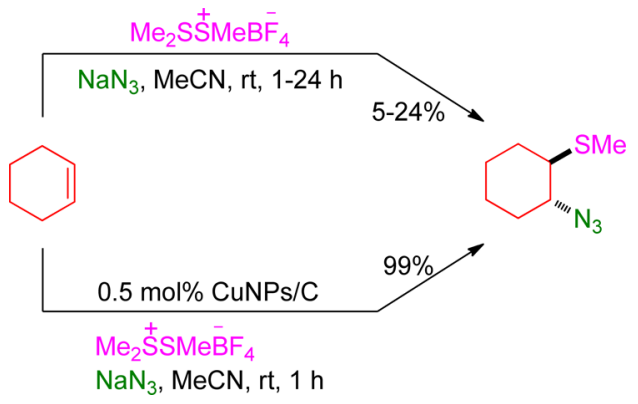

\section{CONCLUSION}

$430 \mathrm{We}$ have summarized the application of easily prepared 431 unsupported and supported CuNPs to CuAAC. The 432 unsupported catalyst, $\mathrm{Cu}(0) \mathrm{NPs}$ in tetrahydrofuran, allowed 433 the fast reaction of terminal alkynes with preformed azides in 434 the presence of triethylamine as a base; however, nanoparticle 435 dissolution under these conditions prevented recovery of the 436 catalyst. The catalysts composed of oxidized CuNPs on 437 activated carbon (CuNPs/C) or silica-coated maghemite 438 nanoparticles (CuNPs/MagSilica) were endowed with salient 439 features that made the click reaction much more efficient and 440 sustainable than with the unsupported counterpart, namely, (a) 441 the three-component version of the CuAAC was applied; (b) 442 reactions were conducted in neat water; (c) low metal loading 443 was used; and (d) the catalyst could be easily recovered and
Scheme 5. Synthetic Transformations of a $\beta$-Methylsulfanyl1,2,3-triazole
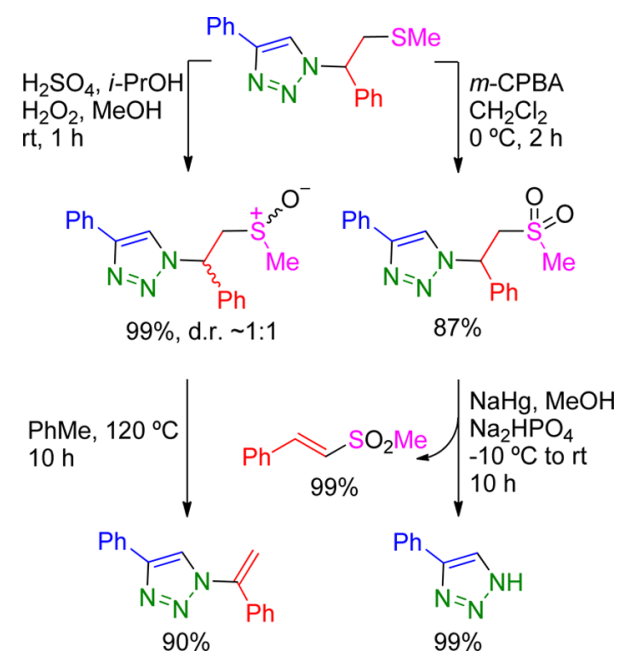

reused. In particular, CuNPs/C displayed high versatility 444 because, using the same conditions in every case, 1,4- 445 disubstituted 1,2,3-triazoles were effectively synthesized from 446 terminal alkynes, sodium azide, and different azido precursors, 447 including organic halides, diazonium salts, anilines, and 448 epoxides. A one-pot protocol was also developed with this 449 catalyst whereby inactivated alkenes could be utilized as azido 450 precursors in the click reaction. Moreover, in all of the above 451 reactions, the performance of CuNPs/C was above that of 452 commercial bulk copper catalysts, once more bolstering the 453 
454 catalytic advantages of nanostructured materials. Further 455 research must be devoted to the design of durable 456 heterogeneous nanocatalysts that would enable click chemistry 457 to be exploited competently on a large scale with negligible 458 copper contamination of the products.

\section{AUTHOR INFORMATION}

\section{Corresponding Author}

461 *E-mail: falonso@ua.es.

\section{Author Contributions}

463 The manuscript was written through contributions of all 464 authors.

465 Notes

466 The authors declare no competing financial interest.

\section{Biographies}

468 Francisco Alonso received his B.Sc. (1986), M.Sc. (1988), and Ph.D. 469 (1991) in Chemistry from the University of Alicante. He was a 470 postdoctoral Fleming Fellow (1992-1994) at the University of Oxford 471 and became an Associate Professor in 1998 at the University of 472 Alicante. His research focuses on the development of new synthetic 473 methodologies involving transition-metal nanoparticles and the 474 application of organometallic intermediates to the synthesis of 475 naturally occurring molecular structures. $\mathrm{He}$ is the Director of the 476 Instituto de Síntesis Orgánica and cofounder of Medalchemy S. L.

477 Yanina Moglie received her B.Sc. (2004) and Ph.D. (2009) in 478 Chemistry from the Universidad Nacional del Sur (UNS) (Bahía 479 Blanca, Argentina). After a postdoctoral stay at the University of 480 Alicante (2010-2013), in 2014 she became a CONICET Associate 481 Researcher of the Instituto de Química del Sur (INQUISUR, Bahía 482 Blanca). Her research focuses on supported metal nanoparticles and 483 their application in organic synthesis.

484 Gabriel Radivoy received his B.Sc. (1990) and Ph.D. (1996) in 485 Chemistry from the UNS. After a three-year postdoctoral stay (1998486 2001) at the University of Alicante, he moved back to the UNS, where 487 he became an Associate Professor in 2009. His research is focused on 488 new synthetic methodologies based on metal nanoparticles as catalysts. $489 \mathrm{He}$ is an Independent Researcher at CONICET and a member of the 490 board of INQUISUR (CONICET-UNS).

\section{ACKNOWLEDGMENTS}

492 This work was supported by the Spanish Ministerio de 493 Economía y Competitividad, the Generalitat Valenciana, 494 Fondo Europeo de Desarrollo Regional, the Argentinian 495 Consejo Nacional de Investigaciones Científicas y Técnicas 496 and Agencia Nacional de Promoción Científica Tecnológica, 497 and the Instituto de Síntesis Orgánica (Universidad de 498 Alicante).

\section{$499 \square$ REFERENCES}

500 (1) Kolb, H. C.; Finn, M. G.; Sharpless, K. B. Click Chemistry: 501 Diverse Chemical Function from a Few Good Reactions. Angew. 502 Chem., Int. Ed. 2001, 40, 2004-2021.

503 (2) (a) Tornøe, C. W.; Meldal, M. Peptidotriazoles: Copper(I)504 Catalyzed 1,3-Dipolar Cycloadditions on Solid-Phase. In The Wave of 505 the Future; Lebl, M., Houghten, R. A., Eds.; American Peptide Society 506 and Kluwer Academic Publishers: San Diego, 2001; pp 263-264. 507 (b) Tornøe, C. W.; Christensen, C.; Meldal, M. Peptidotriazoles on 508 Solid Phase: [1,2,3]-Triazoles by Regiospecific Copper(I)-Catalyzed 509 1,3-Dipolar Cycloadditions of Terminal Alkynes to Azides. J. Org. 510 Chem. 2002, 67, 3057-3064.
(3) Rostovtsev, V. V.; Green, L. G.; Fokin, V. V.; Sharpless, K. B. A 511 Stepwise Huisgen Cycloaddition Process: Copper(I)-Catalyzed 512 Regioselective "Ligation" of Azides and Terminal Alkynes. Angew. 513 Chem., Int. Ed. 2002, 41, 2596-2599.

(4) Huisgen, R.; Knorr, R; Möbius, L.; Szeimies, G. 1.3-Dipolare 515 Cycloadditionen, XXIII. Einige Beobachtungen zur Addition organ- 516 ischer Azide an CC-Dreifachbindungen. Chem. Ber. 1965, 98, 4014- 517 4021.

(5) (a) Bock, V. D.; Hiemstra, H.; van Maarseveen, J. H. Cu ${ }^{\mathrm{I}}-519$ Catalyzed Alkyne-Azide "Click" Cycloadditions from a Mechanistic 520 and Synthetic Perspective. Eur. J. Org. Chem. 2006, 2006, 51-68. 521 (b) Meldal, M.; Tornøe, C. W. Cu-Catalyzed Azide-Alkyne Cyclo- 522 addition. Chem. Rev. 2008, 108, 2952-3015. (c) Fokin, V. V. CuAAC: 523 The Quintessential Click Reaction. In Organic Chemistry-Break- 524 throughs and Perspectives, 1st ed.; Ding, K., Dai, L.-X., Eds.; Wiley- 525 VCH: Weinheim, Germany, 2012; Chapter 7, pp 247-277. 526 (6) (a) Wang, Q.; Hawker, C. Toward a Few Good Reactions: 527 Celebrating Click Chemistry's First Decade. Chem. - Asian J. 2011, 6, 528 2568-2569. (b) For a special issue, see: Chem. - Asian J. 2011, 6, 529 2565-2847.

(7) (a) Click Chemistry for Biotechnology and Materials Science; 531 Lahann, J., Ed.; Wiley: Chichester, U.K., 2009. (b) Thirumurugan, P.; 532 Matosiuk, D.; Jozwiak, K. Click Chemistry for Drug Development and 533 Diverse Chemical-Biology Applications. Chem. Rev. 2013, 113, 4905- 534 4979. 535

(8) Anastas, P.; Eghbali, N. Green Chemistry: Principles and Practice. 536 Chem. Soc. Rev. 2010, 39, 301-312. 537

(9) (a) Nanoparticles and Catalysis; Astruc, D., Ed.; Wiley-VCH: 538 Weinheim, Germany, 2008. (b) Selective Nanocatalysts and Nanoscience, 539 1st ed.; Zecchina, A., Bordiga, S., Groppo, E., Eds.; Wiley-VCH: 540 Weinheim, Germany, 2011. (c) Nanomaterials in Catalysis; Serp, P., 541 Philippot, K., Eds.; Wiley-VCH: Weinheim, Germany, 2013. (d) For a 542 special issue, see: Nanoparticles for Catalysis. Acc. Chem. Res. 2013, 543 46, 1671-1910. (e) Metal Nanoparticles for Catalysis: Advances and 544 Applications; Tao, F., Ed.; Royal Society of Chemistry: Cambridge, 545 U.K., 2014.

(10) Campelo, J. M.; Luna, D.; Luque, R.; Marinas, J. M.; Romero, A. 547 A. Sustainable Preparation of Supported Metal Nanoparticles and their 548 Applications in Catalysis. ChemSusChem 2009, 2, 18-45. 549

(11) Nasir Baig, R. B.; Varma, R. S. Nanocatalysis in Water. In Metal- 550 Catalyzed Reactions in Water; Dixneuf, P. H., Cadierno, V., Eds.; Wiley- 551 VCH: Weinheim, Germany, 2013; Chapter 9, pp 337-394. 552

(12) (a) Himo, F.; Lovell, T.; Hilgraf, R.; Rostovtsev, V. V.; 553 Noodleman, L.; Sharpless, K. B.; Fokin, V. V. Copper(I)-Catalyzed 554 Synthesis of Azoles. DFT Study Predicts Unprecedented Reactivity 555 and Intermediates. J. Am. Chem. Soc. 2005, 127, 210-216. 556 (b) Gommermann, N.; Gehrig, A.; Knochel, P. Enantioselective 557 Synthesis of Chiral $\alpha$-Aminoalkyl-1,2,3-Triazoles Using a Three- 558 Component Reaction. Synlett 2005, 2796-2798.

(13) For reviews, see: (a) Jin, T.; Yan, M.; Yamamoto, Y. Click 560 Chemistry of Alkyne-Azide Cycloaddition Using Nanostructured 561 Copper Catalysts. ChemCatChem 2012, 4, 1217-1229. (b) Woo, 562 H.; Kang, H.; Kim, A.; Jang, S.; Park, J. C.; Park, S.; Kim, B.-S.; Song, 563 H.; Park, K. H. Azide-Alkyne Huisgen [3 + 2] Cycloaddition Using 564 CuO Nanoparticles. Molecules 2012, 17, 13235-13252. 565

(14) (a) For the first applications of finally divided metals in organic 566 chemistry, see: Sabatier, P. La Catalyse en Chimie Organique; Librairie 567 Polytechnique Ch.Béranger: Paris, 1913. (b) Rieke, R. D. Use of 568 Activated Metals in Organic and Organometallic Synthesis. Top. Curr. 569 Chem. 1975, 59, 1-31. (c) Fürstner, A. Active Metals; Wiley-VCH: 570 Weinheim, Germany, 1996.

(15) (a) Alonso, F.; Vitale, C.; Radivoy, G.; Yus, M. Reduction of 572 Carbonyl Compounds and Imines using the $\mathrm{CuCl}_{2} \cdot 2 \mathrm{H}_{2} \mathrm{O}-\mathrm{Li}-\mathrm{DTBB}-573$ (cat.) Combination. Synthesis 2003, 443-447. (b) Alonso, F.; Moglie, 574 Y.; Radivoy, G.; Vitale, C.; Yus, M. Hydrodehalogenation of Organic 575 Halides using the $\mathrm{CuCl}_{2} \cdot 2 \mathrm{H}_{2} \mathrm{O}$-Li-arene(cat.) Combination. Appl. 576 Catal., A 2004, 271, 171-176. (c) Radivoy, G.; Alonso, F.; Moglie, Y.; 577 Vitale, C.; Yus, M. Reduction of Alkyl and Vinyl Sulfonates Using the 578 
$579 \mathrm{CuCl}_{2} \cdot 2 \mathrm{H}_{2} \mathrm{O}-\mathrm{Li}-\mathrm{DTBB}$ (cat.) System. Tetrahedron 2005, 61, 38595803864 .

581 (16) (a) Berg, R.; Straub, J.; Schreiner, E.; Mader, S.; Rominger, F.; 582 Straub, B. F. Highly Active Dinuclear Copper Catalysts for 583 Homogeneous Azide-Alkyne Cycloadditions. Adv. Synth. Catal. 2012, 584 354, 3445-3450. (b) Deraedt, C.; Pinaud, N.; Astruc, D. Recyclable 585 Catalytic Dendrimer Nanoreactor for Part-Per-Million $\mathrm{Cu}^{\mathrm{I}}$ Catalysis of 586 "Click" Chemistry in Water. J. Am. Chem. Soc. 2014, 136, 1209258712098

588 (17) (a) Durán Pachón, L.; van Maarseveen, J. H.; Rothenberg, G. 589 Click Chemistry: Copper Clusters Catalyse the Cycloaddition of 590 Azides with Terminal Alkynes. Adv. Synth. Catal. 2005, 347, 811-815. 591 (b) Orgueira, H. A.; Fokas, D.; Isome, Y.; Chan, P. C.-M.; Baldino, C. 592 M. Regioselective Synthesis of [1,2,3]-Triazoles Catalyzed by $\mathrm{Cu}(\mathrm{I})$ 593 Generated in situ from $\mathrm{Cu}(0)$ Nanosize Activated Powder and Amine 594 Hydrochloride Salts. Tetrahedron Lett. 2005, 46, 2911-2914. 595 (c) Molteni, G.; Bianchi, C. L.; Marinoni, G.; Santo, N.; Ponti, A. $596 \mathrm{Cu} / \mathrm{Cu}$-Oxide Nanoparticles as Catalyst in the "Click" Azide-Alkyne 597 Cycloaddition. New J. Chem. 2006, 30, 1137-1139. (d) Sarkar, A.; 598 Mukherjee, T.; Kapoor, S. PVP-Stabilized Copper Nanoparticles: A 599 Reusable Catalyst for "Click" Reaction between Terminal Alkynes and 600 Azides in Nonaqueous Solvents. J. Phys. Chem. C 2008, 112, 33346013340 .

602 (18) (a) Astruc, D.; Lu, F.; Ruiz Aranzaes, J. Nanoparticles as 603 Recyclable Catalysts: The Frontier between Homogeneous and 604 Heterogeneous Catalysis. Angew. Chem., Int. Ed. 2005, 44, 7852605 7872. (b) Franke, R; Rothe, J.; Pollmann, J.; Hormes, J.; Bönnemann, $606 \mathrm{H}$.; Brijoux, W.; Hindenburg, T. A Study of the Electronic and 607 Geometric Structure of Colloidal Ti ${ }^{0} \cdot 0.5$ THF. J. Am. Chem. Soc. 1996, 608 118, 12090-12097.

609 (19) (a) Alonso, F.; Moglie, Y.; Radivoy, G.; Yus, M. Copper 610 Nanoparticles in Click Chemistry: an Alternative Catalytic System for 611 the Cycloaddition of Terminal Alkynes and Azides. Tetrahedron Lett. 612 2009, 50, 2358-2362. (b) Alonso, F.; Moglie, Y.; Radivoy, G.; Yus, M. 613 Unsupported Copper Nanoparticles in the 1,3-Dipolar Cycloaddition 614 of Terminal Alkynes and Azides. Eur. J. Org. Chem. 2010, 2010, 18756151884

616 (20) Pérez-Balderas, F.; Ortega-Muñoz, M.; Morales-Sanfrutos, J.; 617 Hernández-Mateo, F.; Calvo-Flores, F. G.; Calvo-Asín, J. A.; Isac618 García, J.; Santoyo-González, F. Multivalent Neoglycoconjugates by 619 Regiospecific Cycloaddition of Alkynes and Azides Using Organic 620 Soluble Copper Catalysts. Org. Lett. 2003, 5, 1951-1954.

621 (21) (a) Hein, J. E.; Fokin, V. V. Copper-Catalyzed Azide-Alkyne 622 Cycloaddition (CuAAC) and Beyond: New Reactivity of Copper(I) 623 Acetylides. Chem. Soc. Rev. 2010, 39, 1302-1315. (b) Buckley, B. R.; 624 Heaney, H. Mechanistic Investigations of Copper(I)-Catalysed 625 Alkyne-Azide Cycloaddition Reactions. Top. Heterocycl. Chem. 2012, $62628,1-30$.

627 (22) (a) Nolte, C.; Mayer, P.; Straub, B. F. Isolation of a Copper(I) 628 Triazolide: A "Click" Intermediate. Angew. Chem., Int. Ed. 2007, 46, 629 2101-2103. (b) Straub, B. F. $\mu$-Acetylide and $\mu$-Alkenylidene Ligands 630 in "Click" Triazole Syntheses. Chem. Commun. 2007, 3868-3870. 631 (c) Ahlquist, M.; Fokin, V. V. Enhanced Reactivity of Dinuclear 632 Copper(I) Acetylides in Dipolar Cycloadditions. Organometallics 2007, 633 26, 4389-4391. (d) Buckley, B. R.; Dann, S. E.; Heaney, H. 634 Experimental Evidence for the Involvement of Dinuclear 635 Alkynylcopper(I) Complexes in Alkyne-Azide Chemistry. Chem. 636 Eur. J. 2010, 16, 6278-6284. (e) Worrell, B. T.; Malik, J. A.; Fokin, V. 637 V. Direct Evidence of a Dinuclear Copper Intermediate in $\mathrm{Cu}(\mathrm{I})$ 638 Catalyzed Azide-Alkyne Cycloadditions. Science 2013, 340, 457-460. 639 (23) (a) Lipshutz, B. H.; Taft, B. R. Heterogeneous Copper-in640 Charcoal-Catalyzed Click Chemistry. Angew. Chem., Int. Ed. 2006, 45, 641 8235-8238. (b) Chassaing, S.; Sido, A. S. S.; Alix, A.; Kumarraja, M.; 642 Pale, P.; Sommer, J. Click Chemistry" in Zeolites: Copper(I) Zeolites 643 as New Heterogeneous and Ligand-Free Catalysts for the Huisgen [3 $644+2$ ] Cycloaddition. Chem. - Eur. J. 2008, 14, 6713-6721. (c) Sirion, 645 U.; Bae, Y. J.; Lee, B. S.; Chi, D. Y. Ionic Polymer Supported 646 Copper(I): A Reusable Catalyst for Huisgen's 1,3-Dipolar Cyclo647 addition. Synlett 2008, 2008, 2326-2330. (d) Park, I. S.; Kwon, M. S.;
Kim, Y.; Lee, J. S.; Park, J. Heterogeneous Copper Catalyst for the 648 Cycloaddition of Azides and Alkynes without Additives under Ambient 649 Conditions. Org. Lett. 2008, 10, 497-500. (e) Smith, C. D.; Baxendale, 650 I. R.; Lanners, S.; Hayward, J. J.; Smith, S. C.; Ley, S. V. [3 + 2] 651 Cycloaddition of Acetylenes with Azides to Give 1,4-Disubstituted 652 1,2,3-Triazoles in a Modular Flow Reactor. Org. Biomol. Chem. 2007, 5, 653 1559-1561. (f) For a minireview of heterogeneous AAC, see: 654 Dervaux, B.; Du Prez, F. E. Chem. Sci. 2012, 3, 959-966.

(24) (a) Feldman, A. K.; Colasson, B.; Fokin, V. V. One-Pot 656 Synthesis of 1,4-Disubstituted 1,2,3-Triazoles from In Situ Generated 657 Azides. Org. Lett. 2004, 6, 3897-3899. (b) Appukkuttan, P.; Dehaen, 658 W.; Fokin, V. V.; Van der Eycken, E. A Microwave-Assisted Click 659 Chemistry Synthesis of 1,4-Disubstituted 1,2,3-Triazoles via a 660 Copper(I)-Catalyzed Three-Component Reaction. Org. Lett. 2004, 6, 661 $4223-4225$

(25) (a) Miao, T.; Wang, L. Regioselective Synthesis of 1,2,3- 663 Triazoles by Use of Silica-Supported Copper(I) Catalyst. Synthesis 664 2008, 2008, 363-368. (b) Bénéteau, V.; Olmos, A.; Boningari, T.; 665 Sommer, J.; Pale, P. Zeo-Click Synthesis: $\mathrm{Cu}^{\mathrm{I}}$-Zeolite-Catalyzed One- 666 Pot Two-Step Synthesis of Triazoles from Halides and Related 667 Compounds. Tetrahedron Lett. 2010, 51, 3673-3677.

(26) (a) Laksmi Kantam, M.; Swarna Jaya, V.; Sreedhar, B.; Mohan 669 Rao, M.; Choudary, B. M. Preparation of Alumina Supported Copper 670 Nanoparticles and their Application in the Synthesis of 1,2,3-Triazoles. 671 J. Mol. Catal. A: Chem. 2006, 256, 273-277. (b) Sharghi, H.; Khalifeh, 672 R.; Doroodmand, M. M. Copper Nanoparticles on Charcoal for 673 Multicomponent Catalytic Synthesis of 1,2,3-Triazole Derivatives from 674 Benzyl Halides or Alkyl Halides, Terminal Alkynes and Sodium Azide 675 in Water as a "Green" Solvent. Adv. Synth. Catal. 2009, 351, 207-218. 676 (27) (a) Alonso, F.; Moglie, Y.; Radivoy, G.; Yus, M. Multi- 677 component Synthesis of 1,2,3-Triazoles in Water Catalysed by Copper 678 Nanoparticles on Activated Carbon. Adv. Synth. Catal. 2010, 352, 679 3208-3214. (b) Alonso, F.; Moglie, Y.; Radivoy, G.; Yus, M. Click 680 Chemistry from Organic Halides, Diazonium Salts and Anilines in 681 Water Catalysed by Copper Nanoparticles on Activated Carbon. Org. 682 Biomol. Chem. 2011, 9, 6385-6395.

(28) Alonso, F.; Moglie, Y.; Radivoy, G.; Yus, M. Multicomponent 684 Click Synthesis of Potentially Biologically Active Triazoles Catalysed 685 by Copper Nanoparticles on Activated Carbon in Water. Heterocycles 686 2012, 84, 1033-1044.

(29) Decan, M. R.; Impellizzeri, S.; Marin, M. L.; Scaiano, J. C. 688 Copper Nanoparticle Heterogeneous Catalytic "Click" Cycloaddition 689 Confirmed by Single-Molecule Spectroscopy. Nat. Commun. 2014, 5, 690 4612.

691

(30) Nador, F.; Volpe, M. A.; Alonso, F.; Feldhoff, A.; Kirschning, A.; 692 Radivoy, G. Copper Nanoparticles Supported on Silica Coated 693 Maghemite as Versatile, Magnetically Recoverable and Reusable 694 Catalyst for Alkyne Coupling and Cycloaddition Reactions. Appl. 695 Catal., A 2013, 455, 39-45.

(31) (a) Barral, K.; Moorhouse, A. D.; Moses, J. E. Efficient 697 Conversion of Aromatic Amines into Azides: A One-Pot Synthesis of 698 Triazole Linkages. Org. Lett. 2007, 9, 1809-1811. (b) Moorhouse, A. 699 D.; Moses, J. E. Microwave Enhancement of a 'One-Pot' Tandem 700 Azidation-'Click' Cycloaddition of Anilines. Synlett 2008, 2008, 701 2089-2092.

(32) Amantini, D.; Fringuelli, F.; Piermatti, O.; Tortoioli, S.; Vaccaro, 703 L. Nucleophilic Ring Opening of 1,2-Epoxides in Aqueous Medium. 704 ARKIVOC 2002, 2002 (xi), 293-311.

(33) (a) Yadav, J. S.; Subba Reddy, B. V.; Madhusudhan Reddy, G.; 706 Narasimha Chary, D. Three Component, Regioselective, One-Pot 707 Synthesis of $\beta$-Hydroxytriazoles from Epoxides via 'Click Reactions. 708 Tetrahedron Lett. 2007, 48, 8773-8776. (b) Kumaraswamy, G.; 709 Ankamma, K.; Pitchaiah, A. Tandem Epoxide or Aziridine Ring 710 Opening by Azide/Copper Catalyzed [3+2] Cycloaddition: Efficient 711 Synthesis of $1,2,3$-Triazolo $\beta$-Hydroxy or $\beta$-Tosylamino Functionality 712 Motif. J. Org. Chem. 2007, 72, 9822-9825. (c) Rajender Reddy, K.; 713 Uma Maheswari, C.; Rajgopal, K.; Lakshmi Kantam, M. One-Pot 714 Sequential Synthesis of $\beta$-Hydroxy-1,4-Disubstituted-1,2,3-Triazoles 715 from In-Situ Generated $\beta$-Azido Alcohol by Click Chemistry. Synth. 716 
717 Commun. 2008, 38, 2158-2167. (d) Sharghi, H.; Beyzavi, M. H.; 718 Safavi, A.; Doroodmand, M. M.; Khalifeh, R. Immobilization of 719 Porphyrinatocopper Nanoparticles onto Activated Multi-Walled 720 Carbon Nanotubes and a Study of its Catalytic Activity as an Efficient 721 Heterogeneous Catalyst for a Click Approach to the Three722 Component Synthesis of 1,2,3-Triazoles in Water. Adv. Synth. Catal. 723 2009, 351, 2391-2410. (e) Sharghi, H.; Hosseini-Sarvari, M.; Moeini, 724 F.; Khalifeh, R.; Beni, A. S. One-Pot, Three-Component Synthesis of 725 1-(2-Hydroxyethyl)-1H-1,2,3-Triazole Derivatives by Copper-Cata726 lyzed 1,3-Dipolar Cycloaddition of 2-Azido Alcohols and Terminal 727 Alkynes under Mild Conditions in Water. Helv. Chim. Acta 2010, 93, 728 435-449. (f) Boningari, T.; Olmos, A.; Reddy, B. M.; Sommer, J.; 729 Pale, P. Zeo-Click Chemistry: Copper(I)-Zeolite-Catalyzed Cascade 730 Reaction; One-Pot Epoxide Ring-Opening and Cycloaddition. Eur. J. 731 Org. Chem. 2010, 2010, 6338-6347.

732 (34) Alonso, F.; Moglie, Y.; Radivoy, G.; Yus, M. Multicomponent 733 Click Synthesis of 1,2,3-Triazoles from Epoxides in Water Catalyzed 734 by Copper Nanoparticles on Activated Carbon. J. Org. Chem. 2011, 76, 735 8394-8405.

736 (35) Trost, B. M.; Shibata, T. Nucleophilic Attack on Olefins 737 Initiated by Dimethyl(methylthio)sulfonium Fluoroborate (DMTSF). 738 Azasulfenylation. J. Am. Chem. Soc. 1982, 104, 3225-3228.

739 (36) Alonso, F.; Moglie, Y.; Radivoy, G.; Yus, M. Alkenes as Azido 740 Precursors for the One-Pot Synthesis of 1,2,3-Triazoles Catalyzed by 741 Copper Nanoparticles on Activated Carbon. J. Org. Chem. 2013, 78, 742 5031-5037. 